\title{
The Covid Crisis - A Turning Point in History - It Has to Be!
}

\author{
Andrew Hague* \\ Professor of Advanced Medicine, President of Cell Sonic, Manufacturers of Medical Equipment, United Kingdom
}

*Corresponding author: Andrew Hague, President of Cell Sonic, Professor of Advanced Medicine, President, Cellsonic,

Manufacturers of Medical Equipment, United Kingdom

\section{ARTICLE INFO}

Received: 㗀 June 22, 2020

Published: 慧 June 30, 2020

Citation: Andrew Hague. The Covid Crisis - A Turning Point in History - It Has to Be!. Biomed J Sci \& Tech Res 28(4)-2020. BJSTR. MS.ID.004674.

\section{ABSTRACT}

The covid-19 disease caused by SARS-CoV-2, the COVID-19, virus results in most governments telling their people to stay at home. This lockdown may well lead to more problems from mental stress and economic failure than are caused by the disease. Eventually there will be a vaccine to eliminate SARS-CoV-2 but there will not be a return to normal because the accumulation of disruption will have created irreversible changes, some worse and some better than before

This stone has stood at a crossroads in the north of England for four hundred years. To protect themselves, the villagers had to isolate much the same as we are doing today. Devastation by germs is nothing new (Figures $1 \& 2$ ).

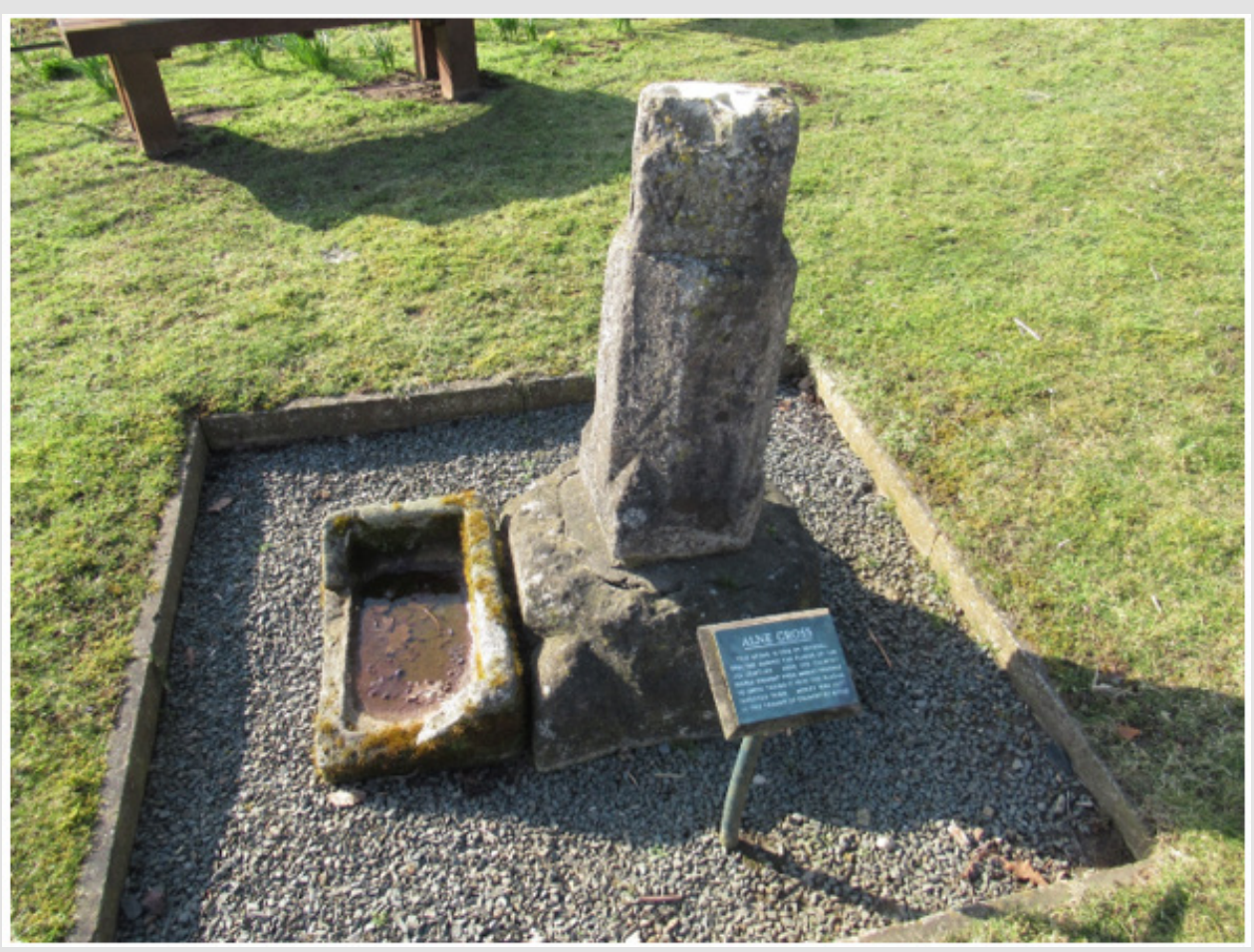

Figure 1. 


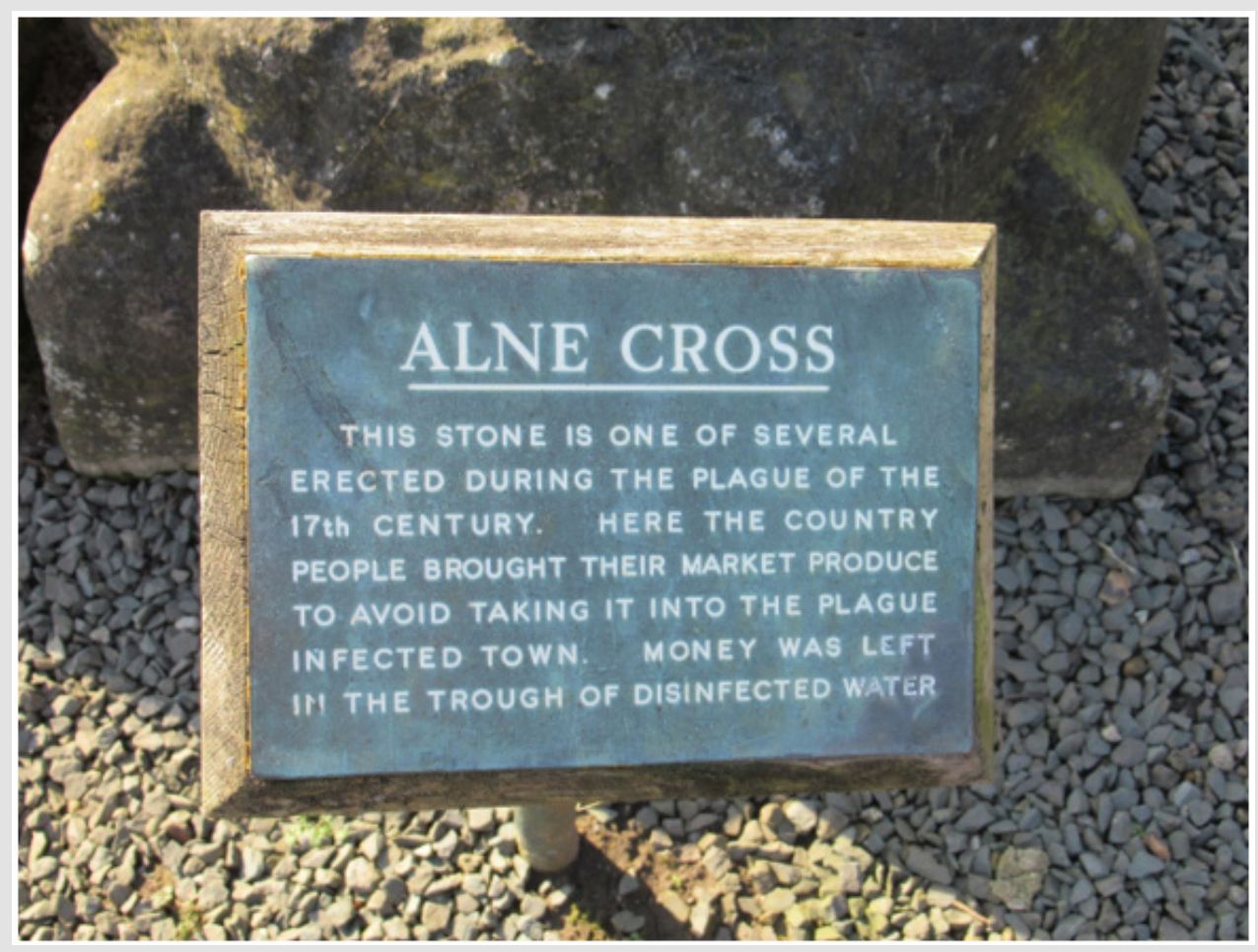

Figure 2.

\section{Introduction}

\section{Worse to Come}

As I write, in May 2020, the Covid Pandemic is not even halfway through its life cycle. Poor countries less affected by international travel await slaughter and, when it comes, lockdowns will not be practical, and the virus will spread uncontrolled. Where there are now lockdowns, people have to live, so to speak, in a bubble. Very few can do this and the mental stress for those who cannot is great. They also are blocked from their normal work so financial problems are inevitable. To study the effects, it is useful to classify people by circumstances according to encumbrances, thus:

i. Independent

ii. Climbers

iii. Chain gang

iv. Trapped

\section{Bubble mentality}

Independents live in a mental bubble. They can see out, but others cannot see in. Survival is independent of moral support from others. A classic example is the music composer, Ludwig van Beethoven who was deaf. He felt isolated causing him great unhappiness He persevered inside the envelope of music in his head even though he could not hear it when it was played. Very few of us can cope in such circumstances. Philosophers, inventors, schemers and crooks, authors and creators may be able to mentally isolate themselves from the restrictions and turmoil around them. They create a mountain top hide-out where they sleep in peace amused only by their own thoughts. In a lockdown, they are the lucky ones. Everyone else is in trouble.

\section{Climbers and Strivers}

Climbers are striving to rise above others. Now unable to be amongst other people, they cannot climb, manage or manipulate. They are stuck and frustrated. These are businesspeople growing by hard work using their own money and borrowings, as a token of faith in the future, who have been closed down by government decree, not their own failings. They are victims, as the months roll on and return to normality recedes, anger will grow. It is amongst this group that mental stress will be greatest and these are the people that normally generate prosperity in the community. When they suffer, everyone does.

\section{Students}

Students are climbers. They have the energy of youth, the education to understand the cause of their plight and a sense of idealism to prevent a recurrence. Throughout history, revolution often starts amongst the students and today their rebellion is expected. They have been thwarted in their hard work to achieve a better future. This is more than the neglect that is causing climate change but neglect it is and worse and for that reason there has to be a fundamental change lest this disaster repeats itself. This where placid lockdown will lead to an explosion out of the myriad of bubbles. They will tolerate isolation so long as it is worthwhile but when international leaders fail to make fundamental changes, those who are our generation of leaders for the future will take action. 


\section{The chain gangs}

The chain gang are people tied together all pulling the load under the direction of the climbers and are now without a common task and separated from their work mates. They are the factory workers, the producers and laborer's. Those who put in the effort and demand some reward of entertainment, comradeship, and a better life for their children than they had. Lockdown has made them redundant. Instead of rubbing shoulders with friends, they are isolated. Watching films is a novelty that evaporates within a few weeks. Frustration leads to anger and someone is to blame for their plight. Revenge would be sweet.

\section{Slaves}

The trapped are the slaves of society. The extreme cases are prisoners, some are unable to be independent and need support. Others are exploited. Their predicament continues. They are unable to be isolated with their chances of infection running high. Whether this leads to riots or slaughter depends on their controllers who are scared silly by a threat never known on this scale before.

\section{The virus genome}

The origins of the virus are known. It has a fascinating genome containing only ten protein coding regions. Most are the usual virus stuff - ORF6, membrane glycoprotein, surface glycoprotein etc. - just the usual virus machinery but the main structural protein is absolutely massive. It is surprising that it is thermodynamically stable. It is extremely unusual to find a protein with more than 300 amino acids in nature. Professor Luc Montagnier, 2008 Nobel Prize winner for Medicine, claims that SARS-CoV-2 is a manipulated virus that was accidentally released from a laboratory in Wuhan, China. Chinese researchers are said to have used coronaviruses in their work to develop an AIDS vaccine. HIV RNA fragments are believed to have been found in the SARS-CoV-2 genome.

\section{Passion turning to anger}

This information is widespread and will cause argument. The truth may never be admitted. What matters are the consequences. Right now, damage is being done. People are dying prematurely of painful deaths. Previously sensible people are drifting to insanity. Hardworking innovators are plotting revenge. Leaders who felt invincible are now scared of something they can't see or control. What will get them, the virus or angry people? Rules of society have been broken forever. More than fifty laboratories are developing a vaccine for SARS-CoV-2. All or some will be effective. Money is unlimited and enough people in the world will be immunized to render the virus extinct. Two years from now, it will all be over. What remains is the fear that some other virus that could be more dangerous will emerge and the whole horrible mess is repeated. It is this fear that causes change.

Almost unique to homo sapiens is the desire to kill each other. They are not content to defend their territory; they strive to conquer others. The history of humanity is the history of wars. Weapons have evolved to become more effective killing machines. They can be directed at an enemy. From a dagger thrust into a victim's chest to a nuclear missile aimed into the basement of a building in another continent, the ability to kill identified people has been the desire of warmongers.

Germ warfare is not new. Poisons have been known as long as food. Placing the poison in the victim has required ingenuity especially for the attacker to avoid becoming a victim. Anthrax was used in warfare. It remains lethal for many years. Experiments on Gruinard Island in Scotland left the island uninhabitable for about fifty years. There has always been a quest for an easy way to kill enemies without harming their environment or turning against the attacker. Nuclear weapons, it is claimed, have the merit of being so devastating that their use results in no victors so they should never be used. Having been proved against Japan in 1945 and later, the explosions at nuclear power stations, particularly Chernobyl in Ukraine, atomic weapons have left a stalemate balance of power with most people forgetting to be worried about them and confident that a mushroom cloud will never reappear.

\section{The rules of war: NO WAR}

Suddenly covid has changed the rules. Aircraft carriers do not work. What was first observed in cruise liners was soon found on these large ships with a crew in confined spaces where the virus spreads. The army, navy and air force operate shoulder to shoulder. They cannot live, train and fight two meters apart from each other. Immunized two years from now, they can return to killing but, even then, the prospect of another virus renders old fashioned fighting pointless. The rules have changed. They can die just waiting for the order to fire. It is amongst the leaders that the fear is greatest. Whether they be democratic or autocratic, the best they can do is keep people away from them and hope that constant cleaning is sufficient protection. They all face an enemy more powerful than each of them can muster in retaliation. To protect themselves, they have to collaborate with others who they may previously have wanted to conquer. Everyone is suddenly in the same boat.

\section{New rules of business: NO DEBT}

When the business leaders and their workers are immunized, they can start up again. Shifts in the market will have occurred. International travel is less attractive and alternatives for communication have been shown to have advantages. These are changing that entrepreneurs take in their stride. What is new is the financing. The companies savaged by the lockdowns were those that entered the closure with low cash reserves and high borrowing. Under normal circumstances, this is a formula for growth and higher returns on capital. Suddenly deprived of sales, the bath of water with an open plug drains away because the taps are shut off and no water flows in. Prudent managers post-covid will be reluctant to borrow, will harbor cash and be content with 
slow growth. Investors will prefer the cautious to the adventurous because it could all happen again. The economic crisis now beginning is the worst in three hundred years. In other words, all the benefits of the industrial revolution, the digital revolution and the medical revolution have disappeared in a viral attack. Standards of living are collapsing and the poor of the world, the majority, face starvation before infection.

\section{International collaboration}

Anger towards China is growing. War against China in revenge will not leave the rest of the world safe. Some other regime could create a worse germ. This much is obvious to all. The only safety net is for all countries of the world to accept that protection for each requires protection for all. Conventional warfare is obsolete and germ warfare is impossible. It cannot conquer, only destroy and is far more destructive than atomic weapons. Dreams of power and becoming leader of the world are no longer practical. Forget whether such power is morally acceptable, can it be done? No, it cannot. Throughout human history, populations have expanded, and prosperity has increased. There have been terrible wars and unnecessary suffering to try to satisfy the egos of idiots. At last, the futility of omnipotence is clear. This has to be the start of permanent peace, co-operation amongst all. I am an optimist. The fear I sense around me will translate into a change of direction for the future. That adage, "if it can go wrong, it will go wrong" will rule the boardrooms of companies and the palaces of rulers. Science got us into this plight and has to get us out of it. From here on, there are no human enemies. Only different people in different places sharing the same planet on which we all depend. Only when confidence returns will business be able to expand and generate prosperous growth. The benefits of energy made by not burning have been experienced so the carbon era will come to an end. State secrets are known to be dangerous to all and the benefits of transparency are proven.

\section{Conclusion}

This crisis will not be solved by lockdowns. Vaccines and herd immunity will not create confidence. It can all happen again. Four hundred years ago there was a plague and plagues have attacked since humans evolved. Now with science, there is some protection. Anti-biotics and vaccines are only protecting against a certain bacteria or virus. The fear of another germ attack will persist and prevent the return of confidence. The fact that the covid attack could have been restricted at the outset, whether it was deliberate or not, tells the whole world that we have to collaborate with each other. We are all in danger and together we must apply science, diplomacy and politics to take us into a new, safe and peaceful world.
ISSN: $2574-1241$

DOI: 10.26717/BJSTR.2020.28.004674

Andrew Hague. Biomed J Sci \& Tech Res

(c) (P) This work is licensed under Creative

Submission Link: https://biomedres.us/submit-manuscript.php

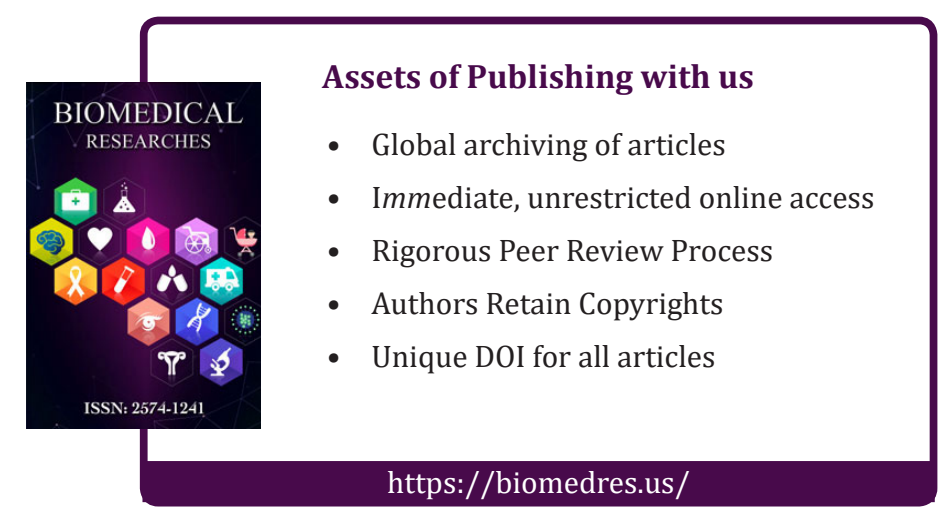

